\title{
The Process Of Creating XBRL Instance Documents: A Research Framework
}

Diane Janvrin, Iowa State University, USA

Maureen Francis Mascha, Marquette University, USA

\begin{abstract}
The past decade has witnessed a technological revolution fueled by the widespread use of the Internet, web technologies, and their applications. Within financial reporting, proponents of extensible Business Reporting Language (XBRL) argue that XBRL will revolutionize financial reporting since it allows corporate financial information to be aggregated, transmitted, and analyzed quicker and more accurately (Hoffman and Strand 2001; Hannon 2002; Bovee et al. 2005; Willis 2005; Cox 2006). The SEC recently mandated that publicly traded companies furnish financial information in XBRL format (Rummel 2008; SEC 2009a). Thus, the purpose of this project is to provide researchers with a framework for examining the process financial statement preparers use to create XBRL instance documents. Further, the paper (1) demonstrates how the framework may be used, (2) raises unanswered questions, and (3) suggests avenues for future research.
\end{abstract}

Keywords: XBRL; electronic financial reporting; instance documents; taxonomy extension

\section{INTRODUCTION}

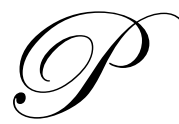

reparers are faced with an ever increasing level of complexity in their financial reporting requirements. To employ XBRL, they are tasked with mating these complex financial statements with an equally complex set of technologies, the XBRL Specification and the appropriate taxonomies. In order to cut through the complexity, these preparers need tools, guidance, and third party assistance to lead them through the process." (Peter Derby, Managing Executive for Operations \& Management, Office of the Chairman, U.S. Securities and Exchange Commission, Boston, Massachusetts, April 26, 2005).

"We continue to have concerns about whether XBRL is ready for broad-based market adoption. Our concerns stem from financial reporting stakeholders' overall lack of awareness and knowledge about XBRL, and a lack of software tools for preparing and analyzing XBRL-formatted documents that are intuitive and easy to use." (KPMG, August 1, 2008).

Proponents of extensible Business Reporting Language (XBRL) claim that the business world is currently witnessing a financial reporting revolution fueled by the capability of XBRL to allow corporate financial information to be aggregated, transmitted, and analyzed quicker and more accurately (Hoffman and Strand 2001; Hannon 2002; Bovee et al. 2005; Willis 2005; Cox 2006; Baldwin et al. 2006). Academic researchers argue that XBRL will help nonprofessional financial statement users acquire and integrate financial information when making investment decisions (Hodge et al. 2004). Regulatory agencies in the U.S. and abroad are beginning to mandateXBRL adoption (CNMV 2005; FDIC 2005; SEC 2005, 2006a, 2007, 2008b; CSA 2007). AICPA publications suggest that XBRL is "unstoppable" (Tie 2005, 32) and will "transform the way CPAs work" (Willis 2005, 80). However, obstacles exist before XBRL can meet these goals. For example, a recent survey of financial preparers noted that 55 percent are just starting to research XBRL or are not aware of the subject at all (Aguilar 2008). Peter Derby, Managing Executive for Operations \& Management, Office of the Chairman, U.S. Securities and Exchange Commission (SEC), noted the need for software tools and guidance to lead preparers through the process of creating XBRL instance documents (i.e., the files containing the tagged financial information formatted 
so that computers can aggregate and analyze information quickly) (Derby 2005). ${ }^{1}$ Several comments during the recent debate regarding the SEC XBRL mandate echo these concerns (Chia 2008; KPMG 2008). The purpose of this paper is to develop a research framework for examining the process financial statement preparers use to create XBRL instance documents.

This research is important since interest in XBRL among academics and financial statement preparers is expected to grow rapidly due to the SEC's recent mandate that public companies furnish XBRL tagged statements (SEC 2008c; 2009a; Twarowski 2008). In addition, audit firms are interested in examining the process of creating instance documents since they are considering using XBRL instance documents and related rendering software to streamline the analytical review process (Bay et al. 2006; Gunn 2007). Furthermore, understanding the instance document creation process is important since errors in the tagging process by financial statement preparers may go unnoticed until the SEC requires companies to file rather than furnish ${ }^{2}$ instance documents. Finally, our research is important to educators as they stress the benefits of XBRL to tomorrow's accountants (Farewell 2006; White 2008).

Our paper proceeds as follows. The second section provides background information on XBRL. The third section presents the research framework. The fourth section demonstrates how the research framework may be used by researchers to examine the process preparers use to create instance documents. The fifth section identifies unanswered questions and avenues for future research based upon the demonstration. Finally, the sixth section summarizes the paper results and its importance.

\section{BACKGROUND INFORMATION ON XBRL}

Maudlin and Ruchala (1999) argue that "technology is a pervasive and growing component of accounting tasks and has been shown to change work processes" (1999, 328). Proponents of XBRL argue that due to its ability to run across platforms, XBRL will change, perhaps even "revolutionize", one important accounting work process, financial reporting (Hoffman and Strand 2001; Hannon 2002; Pinsker 2007). With XBRL, financial statements are no longer treated as a block of text, web page, or printed document (Gunn 2007, A36). Instead, each individual item in the financial statement is assigned an unique, computer-readable identifying tag. These XBRL tags enable financial information to be treated "intelligently" since computers can recognize individual item information in the XBRL tag and can select items, such as net income, from a query search. This information can be stored, analyzed, or even exchanged with other computers.

XBRL provides several benefits to information preparers (i.e., companies required to file financial information with the SEC or other government regulators) and information users (i.e., investors, financial analysts, auditors, and government regulators). With XBRL, information preparers may lower report preparation costs and produce more reliable financial information due to reduced data entry work (Baldwin et al. 2006; Stantial 2007). XBRL tags allow information users to search for and integrate key financial information quickly (Hodge et al. 2004). In addition, with XBRL tagged information, users can perform multiple financial analyses without manually re-entering information (Baldwin et al. 2006). Finally, XBRL may benefit both information preparers and users by facilitating the electronic sharing of financial information (SEC 2005; XBRL US, Inc. 2008).

Several regulatory agencies recognize the importance of XBRL development. The SEC initiated a voluntary XBRL reporting program with expedited review in February 2005 (SEC 2005) and recently mandated that all publicly traded companies furnish financial information in XBRL format by 2011 (SEC 2008b, 2009a). Quarterly Call Reports are now submitted to the Federal Financial Institutions Examination Council (FFIEC) in XBRL format (FDIC 2005; Hannon and Trevithick 2006). In addition, the Canadian Securities Administrators (CSA) began a voluntary XBRL filing program in January 2007 (CSA 2007).

\footnotetext{
${ }^{1}$ Other barriers to widespread XBRL adoption, such as quantifiable benefits to adopters (e.g., what tangible benefits will XBRL adopters receive (Baldwin et al. 2006), and legal issues (e.g., will regulatory agencies mandate XBRL usage (Debreceny et al. 2005)) are beyond the scope of this study.

${ }^{2}$ Financial statements filed with the SEC are generally audited whereas the SEC does not require companies to audit furnished statements (SEC 2008a).
} 
XBRL uses taxonomies to define lists of elements and relationships for specific reporting purposes, such as reporting financial information under U.S. GAAP. To create an instance document, preparers map each financial statement item to an XBRL tag. Generally, each XBRL tag used appears in a standard taxonomy, but preparers may extend standard taxonomies to accommodate individual needs. For example, a floral shop retailer can extend an existing standard taxonomy to set up a 'perishable inventory' XBRL tag for its perishable flower inventory.

There are two types of XBRL software: software to extend taxonomies and create instance documents and software to read instance documents. Software to extend taxonomies and create instance documents allows preparers to tag the individual values in financial statements to corresponding XBRL elements in the taxonomy. Once the instance documents are created, the reader software (also known as instance rendering and printing software (XBRL US, Inc. 2008)) enables users to view the information in a human-readable output and create custom reports. In addition, users may use reader software to compare selected financial information between two or more companies. While several providers are currently marketing reader software or integrating this function into existing software for financial statement users (i.e., analysts and investors), fewer have successfully developed software that enables financial statement preparers to extend taxonomies and create instance documents (SEC 2008a; Chia 2008; KPMG 2008).

\section{FRAMEWORK TO EXAMINE THE PROCESS OF CREATING INSTANCE DOCUMENTS}

Prior XBRL research presents frameworks that examine the expected benefits of XBRL from the broad information quality (e.g., Bovee 2007), assurance (e.g., Gunn 2007), and impact on users (e.g., Baldwin et al. 2006) perspectives. Since instance document creation is a necessary prerequisite in the generation of XBRL-formatted financial statements, we develop a research framework examining the process of creating instance documents.

The framework, shown in Figure 1, suggests that financial statement preparers begin by selecting the software to use based on both software functionality and financial reporting stage. Software to create instance documents may contain different functionalities (XBRL US, Inc. 2008). Some software can be all-inclusive of the required functionality for taxonomy extension, instance document creation, and validation ${ }^{3}$, while other software may offer this functionality separately or as part of a suite of tools. For example, while most software creates instance documents, some simple packages do not allow preparers to extend the taxonomy. Finally, software to extend taxonomies and create instance documents may vary in the availability and quality of the XBRL rendering functions since no standard rendering and format solution currently exists for XBRL (XBRL US, Inc. 2008).

Furthermore, companies may map their information to XBRL tags during at least two stages in the financial reporting process. Typically, early XBRL adopters will prepare the financial statements and map the information to XBRL tags using a bolt-on approach. Alternatively, mapping may occur earlier in the financial reporting process as part of an integrated approach to financial reporting. In an integrated approach, companies incorporate XBRL into their internal financial systems (Plumlee and Plumlee 2008; Trinkle and Henderson 2008). Thus, financial reports can be created from the XBRL tagged financial systems, without such financial statements first being prepared in 'human readable format' (SEC 2008a, 77).

Next, the preparers identify the financial information to tag. Financial information may vary from simple executive compensation to the complete financial statement set including footnotes. After identifying which information to tag, preparers choose a standard taxonomy (i.e. manufacturing, banking, etc.) and download it into the XBRL software product (XBRL US, Inc. 2008). ${ }^{4}$ Preparers may set up the contexts by documenting the entity name, period involved, and segment information (consolidated, audited, unaudited, actual, plan, etc.) that collectively give the appropriate information for understanding the numeric or non-numeric data items or individual facts in the instance document (XBRL US, Inc. 2008).

\footnotetext{
${ }^{3}$ Validation refers to identifying any errors in the XBRL specification (XBRL US, Inc. 2008).

${ }^{4}$ Approved taxonomies are available at: $\underline{w w w . x b r l . o r g}$.
} 
Next, each individual account value must be separately mapped to (or tagged with) a specific XBRL element (i.e., account identifier) from the standard taxonomy. Each summary value, such as 'total current assets' and 'total long-term assets', is also mapped to a separate XBRL tag. If the standard taxonomy does not include an appropriate element, the financial statement preparer may extend the standard taxonomy by creating a new XBRL element.

The "tagging" process is then validated (or edited by the software) to identify any errors in the XBRL specification (XBRL US, Inc. 2008). Once errors are corrected, the software generates the instance document. Similar to other filings, senior accounting management reviews the instance document for reasonableness and obvious errors (XBRL US, Inc. 2008). Whether this instance document should be audited before issuance remains an issue for debate (Plumlee and Plumlee 2008; Boritz and No 2009; Srivastava and Kogan 2009). Finally, financial statement preparers issue the instance document for external parties to use with XBRL reader software to analyze company performance.

Figure 1: Process to Extend Taxonomies and Create XBRL Instance Documents

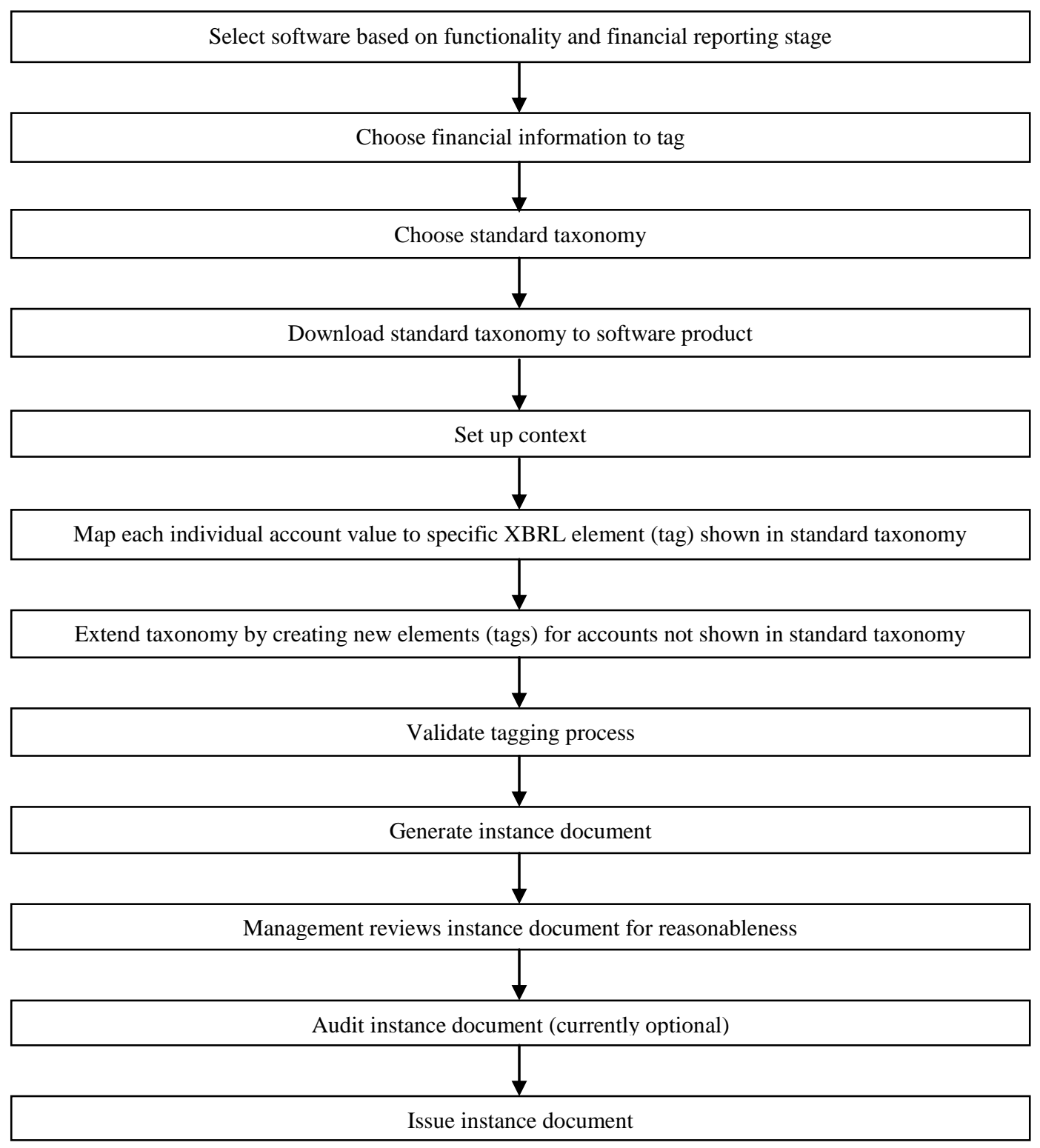




\section{Examining User Perceptions of Software to Create Instance Documents}

To create instance documents, preparers generally use software designed for this task. Information systems literature can assist researchers to understand preparers' perceptions of this software. Specifically, researchers can measure preparers' willingness to accept and use the software, their effort required to use the software, and their qualitative perceptions of the software.

\section{Measure Preparers' Willingness to Accept and Use Software}

The acceptance of new technologies has been extensively examined in information systems research (Lucas 1975; DeSanctis 1983; Segars and Grover 1993; Straub et al. 1995; Doll et al. 1998). While several theoretical frameworks exist to predict acceptance of new technology, TAM (Davis 1989) is one of the most influential given its grounding in Fishbein and Ajzen's (1975) theory of reasoned action, parsimony, and empirical support (Mathieson 1991; Markus and Keil 1994; Hu et al. 1999; Ma and Liu 2004; Malhotra and Galletta 2004). ${ }^{5}$ According to the theory of reasoned action, beliefs influence attitudes, which in turn lead to intentions, which then guide or generate behaviors (Davis et al. 1989). TAM relates perceptions of usefulness and ease of use to behavioral intention to use new technology. Perceived usefulness refers to the degree to which an individual believes that using a particular system will enhance his/her job performance (Davis 1989, 320). In contrast, perceived ease of use identifies the degree to which an individual believes that using a particular system would be free of effort (Davis 1989, 320). Perceived ease of use is a necessary precursor to preparer acceptance, but only if the preparer first perceives usefulness. Thus, perceived usefulness is necessary, although not sufficient, for preparer acceptance to occur since participants may not accept software which is perceived as easy to use, but not useful.

\section{Measure Effort Required}

Measuring effort required to use software is often difficult. Many researchers use time spent on software as a proxy for effort. However, using time as a proxy for effort may be noisy. Psychology research indicates that individuals performing a wide variety of tasks often make speed/accuracy tradeoffs (Forster et al. 2003). For example, an accountant may elect to perform a financial analysis quickly to meet the time demands of the chief executive officer while acknowledging that the analysis would be more accurate if he/she took more time. Similarly, a speed/accuracy tradeoff may exist for information preparers (Ballou and Pazer 1995). A preparer may perceive that due to its interface, he/she can use the features of one software application relatively quickly. He/she then moves on to other tasks without understanding one or more critical software features. In contrast, the preparer may find a second software application more time consuming to use; but by spending the extra time with the software, he/she may understand more critical software features. Collopy (1996) finds that self-reported time is comparable with the total logged measure of connect time. Furthermore, several previous information systems studies employ a self-reported time measure (Edberg and Bowman 1996; Janvrin and Morrison 2000; Panko 2000; Morrison et al. 2002).

\section{Examine Preparers' Qualitative Perceptions}

To effectively examine users' perceptions of software, evaluation data may be either qualitative or quantitative (Davis 1989; Mamaghani 2002). Qualitative information is often helpful when examining new technology and processes (Aladwani and Palvia 2002; McCloskey 2006); thus, we recommend that researchers obtain qualitative information from preparers by using either pre-specified or open-ended questions.

\section{FRAMEWORK DEMONSTRATION}

To demonstrate how researchers can use our framework to examine the process of creating instance documents, we asked participants to use one of two software packages: Dragon Tag or Interstage XWand. We chose these software packages since they (1) were two of the earliest available that included the required functionality for

\footnotetext{
${ }^{5}$ Other accounting researchers have used information systems theoretical frameworks to predict acceptance (or adoption) of new accounting technology (e.g., Walsh and White 2000; Bedard et al. 2003) and budgeting methods (West and Davis 2008).
} 
taxonomy extension, instance document creation, and validation, (2) are fairly representative of the marketplace for bolt-on software (Stantial 2007; Mahoney and White 2007; Mascha et al. 2009), and (3) were used by several SEC early XBRL adopters (see Phillips et al. 2008). ${ }^{6}$

\section{Task and Procedure}

We randomly assigned participants either Dragon Tag or Interstage XWand software and asked them to extend a taxonomy to create a new XBRL tag and tag two basic financial statements (shown in Appendix A). The demonstration was conducted during two sessions. In the first session, participants (1) completed a pre-project questionnaire (see Appendix B) to obtain basic demographic information and XBRL familiarity level, (2) reviewed general XBRL software concepts, (3) learned how to use the assigned software (i.e., Dragon Tag or Interstage XWand), and (4) created a balance sheet instance document which included extending the standard taxonomy to add a balance sheet element titled 'Flowers Inventory'.

In the following session, participants (1) created an income statement instance document which included adding an income statement element titled 'Interest and Taxes' to the existing taxonomy ${ }^{7}$, and (2) completed a postproject questionnaire (see Appendix C) to obtain perceived usefulness and ease of use information via TAM questions adopted from Davis (1989) and qualitative perceptions of the assigned software.

Determining what information for participants to tag was difficult. We planned to ask participants to tag a complete set of financial statements including footnotes. However, the available taxonomies ${ }^{8}$ when the demonstration was run only allowed participants to tag each footnote as a block. Also, we considered using financial statements involving rolling up subsidiary (i.e., division) information into consolidated financial statements. However, the version of Dragon Tag and Interstage XWand we examined did not include this capability. Thus, we required participants to tag the balance sheet and income statement for a fictitious company without footnotes or subsidiary information. Furthermore, we elected not to incorporate the audit function since currently only one company participating in the voluntary filing program furnishes audited XBRL instance documents to the SEC (Boritz and No 2009).

\section{Subjects}

Given the exploratory nature of this demonstration and the slow adoption of XBRL, finding appropriate subjects to examine XBRL instance document creation was difficult. We ran a pilot study with 18 practicing CPAs and 24 undergraduate accounting information systems students. Interestingly, the accounting information systems students were more familiar with XBRL than the practicing CPAs. Based on these results and discussions with several controllers who suggested that if and when their companies adopt XBRL, the actual XBRL tagging would be performed by newer accountants with accounting information systems experience, our participants were 216 accounting information systems students at two Midwestern universities. ${ }^{9}$ Participants completed the project after obtaining significant hands-on experience with non-XBRL software applications. As shown in Table 1, 119 males and 97 females participated. Participants' knowledge of XBRL concepts was relatively low. However, participants rated their mean comfort level with (1) learning new software at 3.64 on a seven-point scale where $1=$ novice and 7 $=$ expert, and (2) computers in general at 4.09 on a similar seven-point scale.

\footnotetext{
${ }^{6}$ In addition, Dragon Tag is now recommended by at least one Big 4 firm to its clients who lack XBRL software (Rivet Software 2007).

${ }^{7}$ A research assistant reviewed all instance documents to ensure participants assigned proper tags, created an extension taxonomy, and applied the extension taxonomy appropriately.

${ }^{8}$ The demonstration used US GAAP Commercial and Industrial (US-GAAP-CI) Taxonomy Specification 2.1 issued February 28 , 2005.

${ }^{9}$ Data was collected over two semesters. Given there were no statistically significant differences in responses between universities or semesters, we pooled all responses.
} 
Table 1: Framework Demonstration Participant Demographics $\mathrm{n}=\mathbf{2 1 6}$

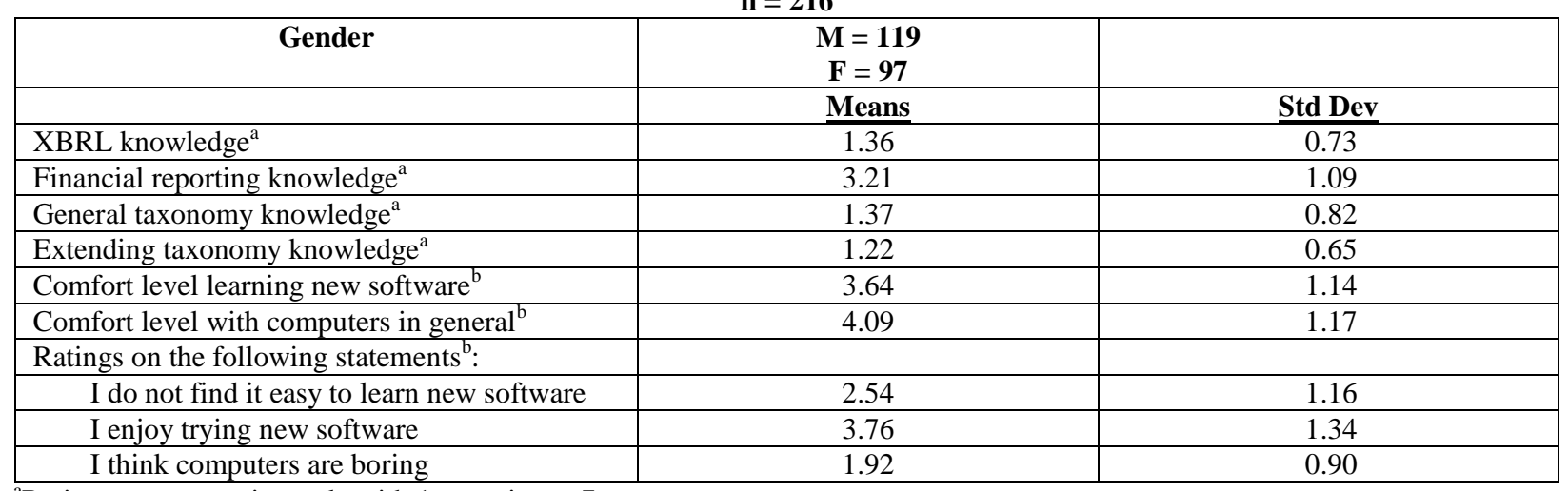

${ }^{\mathrm{a}}$ Rating on seven point scale with $1=$ novice to $7=$ expert.

${ }^{\mathrm{b}}$ Rating on scale of $1=$ disagree to $7=$ agree.

\section{RESULTS}

To evaluate whether preparers are willing to accept and use XBRL software, we measured users' willingness to accept technology (Davis 1989). In order to determine if the questions designed to capture perceived usefulness and ease of use load appropriately on the intended factor, we performed a confirmatory factor analysis (Pedhazur and Schmelkin 1991). Cronbach Alphas were 0.94 and 0.92 respectively. Additionally, factor analysis indicates that the questions designed to measure perceived usefulness and ease of use load on one factor alone, with alpha values for each individual question exceeding 0.82 in all cases (See Appendix D).

Based on these results, we proceeded with our analysis using perceived usefulness and ease of use as variables. As shown in Table 2, participants extending taxonomies and creating instance documents with Dragon Tag rated its perceived usefulness as 3.64 on a five point scale where $1=$ strongly disagree and $5=$ strongly agree while those using Interstage XWand rated its perceived usefulness statistically lower at $3.41(\mathrm{p}=0.01)$.

Table 2: Framework Demonstration Technology Acceptance Mean Ratings ${ }^{\text {a }}$ $\mathrm{n}=216$

\begin{tabular}{|l|c|c|}
\hline & Dragon Tag Means (Std Dev) & Interstage XWand Means (Std Dev) \\
\hline Perceived usefulness & & $3.41^{*}$ \\
& 3.64 & $(0.64)$ \\
\hline Perceived ease of use & $(0.75)$ & $2.70^{* *}$ \\
& 3.01 & $(0.67)$ \\
\hline
\end{tabular}

${ }^{\mathrm{a}}$ Rating based on a five point Likert scale where $1=$ strongly disagree and $5=$ strongly agree.

$* *$ Two tailed t test analysis indicates responses differ by software at $\mathrm{p} \leq 0.01$ level.

* Two tailed $\mathrm{t}$ test analysis indicates responses differ by software at $\mathrm{p} \leq 0.05$ level.

TAM suggests that perceived ease of use is a necessary precursor to preparer acceptance but only if the preparer first perceives the application will be useful to enhance his/her job performance. Participants assigned to Dragon Tag rated its perceived ease of use at 3.01 while those using Interstage XWand rated perceived ease of use statistically lower at $2.71(\mathrm{p}<0.01) .{ }^{10}$ Thus, while participants assigned higher ratings to perceived usefulness, the moderate perceived ease of use ratings suggest that improvements in ease of usage are needed before XBRL software will be readily accepted by preparers.

\footnotetext{
${ }^{10}$ Given the unequal gender distribution, we ran ANOVAs to determine if our results were driven by gender differences. Gender was not statistically significant. We also ran ANOVAs to determine if our results were driven by XBRL knowledge, financial reporting knowledge, taxonomy knowledge, taxonomy extension knowledge, new software comfort level, and/or computer comfort level. Results indicate that these factors did not affect our findings.
} 
Table 3:Framework Demonstration Qualitative Perceptions

Panel A: Advantages of Using Software to Create Instance Documents ${ }^{\mathrm{a}}$ Dragon Tag $(\mathbf{n}=114)$

Easy to use

Fast process

Ability to identify and correct errors

Consistent interface

Number of Responses

112

46

28

Interstage XWand $(\mathbf{n}=\mathbf{1 0 2})$

25

Easy to use

Number of Responses

Consistent interface

Fast process

Generates professional looking output

88

46

33

16

Panel B: Challenges of Using Software to Create Instance Documents ${ }^{\mathrm{a}}$

Dragon Tag $(n=114)$

Difficult to identify and correct errors

Interface is difficult to follow

Hard to use software

Difficult to tag financial values

Interstage XWand $(\mathrm{n}=\mathbf{1 0 2})$

Interface is difficult to follow

Hard to use software

Difficult to tag financial values

Difficult to identify and correct errors

${ }^{a}$ Participants were asked to list three advantages and three disadvantages they experienced while using their assigned software to create an instance document.

Panel C: Advantages of Using Software to Extend a Taxonomy ${ }^{b}$

Dragon Tag $(n=114)$

Easy to use

Consistent interface

Fast process

Easy to insert new elements into taxonomy

Interstage XWand $(\mathrm{n}=\mathbf{1 0 2})$

Easy to use

Consistent interface

Easy to insert new elements into taxonomy

Fast process
Number of Responses

73

39

33

26

Number of Responses

61

31

30

24
52

6

\section{2}

34

20

Panel D: Challenges of Using Software to Extend a Taxonomy ${ }^{b}$

Dragon Tag $(n=114)$

Interface is difficult to follow

Difficult to add new elements into taxonomy

Difficult to find and correct errors

Hard to use software

Interstage XWand $(\mathrm{n}=\mathbf{1 0 2})$

Interface is difficult to follow

Difficult to add new elements into taxonomy

Hard to use software

Difficult to find and correct errors

${ }^{\mathrm{b}}$ Participants were asked to list three advantages and three disadvantages they experienced while using their assigned software to extend a taxonomy.
Number of Responses

37

33

30

24

Number of Responses

53

33

30

10 
To measure effort required to use the software in terms of time, participants self-reported time in fifteen minute increments. Responses suggest most participants took between 30 and 59 minutes. ANOVA analysis found no statistically significant difference in time spent between Dragon Tag and Interstage XWand $(F=0.18 ; p=0.67)$.

We obtained qualitative information from preparers using both pre-specified and open-ended questions. To examine the level of difficulty required to extend a taxonomy, participants rated their perceptions of the ability to extend an existing XBRL taxonomy for the software they evaluated on a scale of 1 to 5 where $1=$ strongly disagree and $5=$ strongly agree. The mean rating for participants examining Dragon Tag was 2.45 while participants using Interstage XWand rated its ability as 2.29. These ratings are not statistically different $(\mathrm{t}=1.45, \mathrm{p}=0.15)$. Interestingly, given the participants used a five-point Likert scale, these ratings indicate that neither software is extremely useful when preparers extend a taxonomy.

In addition, participants listed three advantages and challenges regarding use of these software applications in general and to extend a taxonomy. ${ }^{11}$ Results, shown in Panels A and B of Table 3, suggest that easy to use, consistent interface, and process speed were cited most frequently as advantages for both software applications. In addition, participants examining Dragon Tag noted its ability to identify and correct errors while Interstage XWand participants cited its ability to generate professional looking output. While participants appreciated the consistent interface, they found it difficult to follow. Participants using either Dragon Tag or Interstage XWand software also found the interface hard to use and had difficulty mapping financial values. In addition, participants found identifying and correcting errors in Dragon Tag a challenge more often than did those participants using Interstage XWand. These responses support the general findings of low ease of use and translate into a low preparer acceptance score. Based on participants' comments, both applications appear to suffer from general design issues.

Participants also identified three advantages and disadvantages to using the software specifically to extend an existing taxonomy. Results, shown in Panels C and D of Table 3, indicate that participants found both software tools easy to use with consistent interfaces. The disadvantages centered on interface issues, ability to add new elements, and confusion over making corrections. Taken together, these findings suggest that software vendors need to focus on automating the "tagging" process and clarifying the correction phase in order to increase perceived ease of use.

\section{Data Availability}

Data used in this study is available from the authors on request at djanvrin@iastate.edu.

\section{UNANSWERED QUESTIONS AND FUTURE RESEARCH OPPORTUNITIES}

We encountered several unanswered questions during our demonstration that led to future research opportunities as listed in Figure 2. Future research is particularly important given that nearly 80 percent of financial preparers recently surveyed indicated their companies had no XBRL expert on staff (Aguilar 2008) and all US publicly traded companies will be required to furnish financial information in XBRL format by 2011 (SEC 2008c, 2009a).

First, the taxonomy available when we conducted the demonstration did not allow us to tag individual footnote components. Thus, future research may compare the advantages of tagging footnotes in blocks with tagging each footnote component. Further, we elected to use simple financial statements in our demonstration while acknowledging that more complex statements may be more realistic. Also, our demonstration involved unaudited financial statements. Future research could explore how using audited financial information may impact user perceptions since regulators are discussing whether external auditors should examine and issue an opinion on the XBRL tagging process (SEC 2008a; Srivastava and Kogan 2009).

\footnotetext{
${ }^{11}$ To analyze these responses, we developed a list of possible advantages and challenges based on prior research and discussions with accounting professionals. An independent coder unaware of the research objective and one co-author classified each advantage and disadvantage according to this list. Consensus between coders was high and disagreements were resolved through discussion between the coder and authors.
} 
Figure 2: Unanswered Questions and Future Research Opportunities from Research Framework Demonstration

\begin{tabular}{|c|c|c|}
\hline Framework Step & Unanswered Question & Future Research Opportunity \\
\hline \multirow[t]{8}{*}{$\begin{array}{l}\text { Understand process to } \\
\text { extend taxonomies and } \\
\text { create instance documents }\end{array}$} & $\begin{array}{l}\text { Will user perceptions differ between } \\
\text { software that is designed to be an add-in vs. } \\
\text { software that has the capability to be either } \\
\text { a stand-alone product or an add-in to a } \\
\text { larger ERP system? }\end{array}$ & $\begin{array}{l}\text { Compare user perceptions of add-in software to } \\
\text { software designed to either be a stand-alone } \\
\text { product or an add-in to a larger ERP system. }\end{array}$ \\
\hline & $\begin{array}{l}\text { Can bolt-on software be used if preparers } \\
\text { adopt an integrated approach and } \\
\text { incorporate XBRL into their internal } \\
\text { financial systems? }\end{array}$ & $\begin{array}{l}\text { Determine whether bolt-on software can be } \\
\text { used by preparers who expand and integrate } \\
\text { XBRL into their internal financial systems }\end{array}$ \\
\hline & $\begin{array}{l}\text { Will preparers tag footnotes in blocks or tag } \\
\text { each footnote component? }\end{array}$ & $\begin{array}{l}\text { Compare the advantages of tagging footnotes in } \\
\text { blocks with tagging each footnote component. }\end{array}$ \\
\hline & $\begin{array}{l}\text { Can simple financial statements be used } \\
\text { when examining the process to create } \\
\text { XBRL instance documents? }\end{array}$ & $\begin{array}{l}\text { Compare quantitative and qualitative results } \\
\text { using simple financial statements to using more } \\
\text { realistic and complex statements. }\end{array}$ \\
\hline & $\begin{array}{l}\text { Can unaudited financial statements be used } \\
\text { when examining the process to create } \\
\text { XBRL instance documents? }\end{array}$ & $\begin{array}{l}\text { Compare results and user perception of } \\
\text { accuracy using unaudited vs audited financial } \\
\text { statements in tagging process. }\end{array}$ \\
\hline & $\begin{array}{l}\text { Should the XBRL tagging process be } \\
\text { audited? }\end{array}$ & $\begin{array}{l}\text { Compare tagging accuracy of unaudited vs. } \\
\text { audited instance documents. }\end{array}$ \\
\hline & $\begin{array}{l}\text { Who are the most appropriate subjects to } \\
\text { use when examining the process to create } \\
\text { XBRL instance documents? }\end{array}$ & $\begin{array}{l}\text { Identify the technology background of } \\
\text { individuals currently tagging financial } \\
\text { statements. }\end{array}$ \\
\hline & $\begin{array}{l}\text { Will results differ when using participants } \\
\text { with greater knowledge of XBRL concepts? }\end{array}$ & $\begin{array}{l}\text { Identify the knowledge of XBRL concepts that } \\
\text { individuals currently tagging financial } \\
\text { statements possess and whether XBRL } \\
\text { knowledge correlates with tagging accuracy. }\end{array}$ \\
\hline \multirow[t]{2}{*}{$\begin{array}{l}\text { Measure preparers' } \\
\text { willingness to accept and } \\
\text { use software }\end{array}$} & $\begin{array}{l}\text { What improvements can developers make to } \\
\text { software to increase participants' ease of } \\
\text { usage ratings? }\end{array}$ & $\begin{array}{l}\text { Test possible improvements to software to } \\
\text { increase ease of usage ratings. }\end{array}$ \\
\hline & $\begin{array}{l}\text { Why did participants rate Dragon Tag } \\
\text { higher in both perceived usefulness and } \\
\text { perceived ease of use than Interstage } \\
\text { XWand? }\end{array}$ & $\begin{array}{l}\text { Examine how differences between Dragon Tag } \\
\text { and Interstage XWand may influence } \\
\text { differences in perceived usefulness and } \\
\text { perceived ease of use. }\end{array}$ \\
\hline $\begin{array}{l}\text { Measure effort required to } \\
\text { use software }\end{array}$ & $\begin{array}{l}\text { Will our results differ if we extend the } \\
\text { definition of effort beyond time required to } \\
\text { include cognitive effort and length of } \\
\text { learning curve? }\end{array}$ & $\begin{array}{l}\text { Examine how cognitive effort required and } \\
\text { length of learning curve may impact effort } \\
\text { results. }\end{array}$ \\
\hline \multirow{3}{*}{$\begin{array}{l}\text { Examine preparers' } \\
\text { qualitative perceptions of } \\
\text { software }\end{array}$} & $\begin{array}{l}\text { How can the ability to extend a taxonomy } \\
\text { be improved? }\end{array}$ & $\begin{array}{l}\text { Develop and evaluate ways to improve how } \\
\text { users extend a taxonomy. }\end{array}$ \\
\hline & $\begin{array}{l}\text { How can the process of mapping financial } \\
\text { values to XBRL tags be improved? }\end{array}$ & $\begin{array}{l}\text { Develop and evaluate ways to improve the } \\
\text { process of mapping financial values to XBRL } \\
\text { tags. }\end{array}$ \\
\hline & $\begin{array}{l}\text { How can the process of identifying and } \\
\text { correcting errors be improved? }\end{array}$ & $\begin{array}{l}\text { Develop and evaluate ways to improve the } \\
\text { process of identifying and correcting errors. }\end{array}$ \\
\hline
\end{tabular}


Additionally, in conducting our demonstration, we debated how to identify the most appropriate subjects to use when examining the process to create instance documents. Given that XBRL is not used significantly in the business world yet (SEC 2007, 2008a), few practicing accountants have experience extending taxonomies and preparing XBRL instance documents. Discussions with several controllers indicated that when they adopt XBRL, the actual XBRL tagging would be done by newer accountants with accounting information systems experience. We used accounting information systems students in our demonstration. However, their low knowledge of XBRL concepts concerned us. Thus, we encourage researchers to examine whether these students or professional accountants are the most appropriate subjects and whether knowledge of XBRL concepts may correlate with tagging accuracy.

Furthermore, to create instance documents, preparers must be willing to accept and use available software. When measuring the willingness to accept and use software, we noted low ease of usage ratings. We suggest that future research develop and test possible software improvements to increase ease of usage ratings. In addition, we found that participants rated Dragon Tag higher in both perceived usefulness and perceived ease of usage than Interstage XWand. Future research could examine what features influenced this rating difference.

When measuring effort required to use XBRL software to create instance documents, our measurement of effort includes only time spent using software. However, individuals may make speed/accuracy tradeoffs (Ballou and Pazer 1995; Forster et al. 2003). Further, one voluntary XBRL provider encourages other companies to internally tag their financial statements by noting that after a time-consuming initial tagging process, subsequent tagging requires significantly less time (Stantial 2007). Thus, research examining other measures such as cognitive effort required and length of learning curve may be warranted.

Examining preparers' qualitative perceptions of software generated additional unanswered questions. Specifically, we noted that researchers could develop and evaluate ways to improve how a user extends a taxonomy, maps financial values to XBRL tags, and identifies and corrects tagging errors.

Our results are subject to limitations. Specifically, in our demonstration, financial statement preparers were assigned software to use to create instance documents. Given that prior research suggests that mandatory software usage may impact user perceptions (Venkatesh and Davis 2000), future research could examine whether results would differ if subjects were allowed to choose a software package. Second, as acknowledged earlier, our participants had low XBRL concepts and had only two exposures to XBRL software. Prior results suggest that preparer perceptions toward technology may change over time because of multiple exposures to software (Venkatesh and Davis 2000). Thus, additional research exploring whether preparer perceptions of XBRL software changes when the participants have more XBRL knowledge in a multi-period setting may be warranted.

\section{CONCLUSION}

The SEC recently mandated that publicly traded companies furnish XBRL instance documents (SEC 2008c, 2009a). Thus, this study concentrates on one obstacle, understanding the process to create instance documents. The purpose of this paper is to present a research framework for examining the process financial statement preparers use to create instance documents. Furthermore, since software to create XBRL instance documents is an important component of the creation process, we suggest methods to consider when evaluating various software packages. We also identify unanswered research questions. Finally, we demonstrate how our framework may be applied by asking participants to create instances documents using one of two early XBRL software packages used by SEC voluntary filing program participants.

Our research provides both theoretical and practical contributions. First, we extend accounting information systems research by focusing on financial statement preparer tasks involving extending standard taxonomies and creating instance documents. While XBRL will impact both financial statement preparers and users (Hannon 2002; Hodge et al. 2004; Willis 2005), we focus on preparer tasks since accountants are likely to perform these tasks. Furthermore, research examining the process to create XBRL instance documents may benefit audit firms that streamline their analytical review process by tagging client financial statements with internally-developed XBRL taxonomies (Bay et al. 2006). Also, understanding the process to create instance documents may assist researchers 
as they work to develop remedies to reduce tagging errors (Bonner 1999; Boritz and No 2008). Second, we provide researchers with a framework to use since the SEC now requires public companies furnish XBRL-tagged instance documents (SEC 2008b; Twarowski 2008). Third, we suggest using the TAM model to understand how one group of professional knowledge workers (i.e., professional accountants) reacts to new software (Bedard et al. 2007). Because TAM has been validated in a wide variety of settings with different technologies, it offers a consistent benchmark for evaluating whether or not users perceive the XBRL software to be useful and/or easy to use (Ma and Liu 2004; Venkatesh et al. 2003).

We expect that the rapid pace of change will continue for the financial reporting environment and for the demand for XBRL instance documents as the SEC works to replace its EDGAR system with an XBRL-based system (SEC 2006b, 2008b). Whether assigning financial items XBRL tags will continue as an after-the-fact (i.e., bolt-on) extra task or be integrated into newer accounting systems remains to be seen. Also, as noted earlier, some companies may elect to outsource tagging their financial statements to third party providers. With the demand for XBRL instance documents increasing and recent surveys suggesting companies are unprepared for XBRL (Aguilar 2008; Rappeport 2008), additional research examining the process to create XBRL instance documents is warranted. The framework presented in this paper is designed to assist researchers with this task.

\section{ACKNOWLEDGEMENT}

We appreciate the helpful comments and encouragement of Matosomo Gato, Neil Hannon, Wayne Harding, Charlie Hoffman, Won No, Paul Pentler, Paul Polinski, and Liv Watson. We received helpful feedback from Rick Dark, Bill Dilla, Rob Pinsker, four anonymous reviewers, the AAA Seventeenth Annual Research Workshop on Artificial Intelligence and Emerging Technologies in Accounting, Auditing, and Tax, and the 2008 XBRL Education Conference. We gratefully acknowledge the assistance of Nicole Bogler, Winston Chappell, Sarah Erdman, Kent Flores, Molly Lampe, Martin Kamenski, Nathan Knies, Leslie Pease, Joseph Plouff, Abby Reinert, Omar Torrens, Pat Wagaman, Brad White, and the study participants.

\section{AUTHOR INFORMATION}

Dr. Diane Janvrin is an Associate Professor of Accounting at Iowa State University. She holds a BA in Management from Central College of Pella IA, a MS and PhD from University of Iowa. She is a CPA, CMA, and CIA.

Dr. Maureen Mascha is an Assistant Professor of Accounting at Marquette University. She holds a BS in Commerce and an MBA from DePaul and a PhD from Kentucky. She is a CPA and CISA.

\section{REFERENCES}

1. Aguilar, M.K. 2008. Survey: Many unprepared for XBRL. Compliance Week July 1. Available at: http://www.complianceweek.com/.

2. Aladwani, A.M., and P.C. Palvia. 2002. Developing and validating an instrument for measuring userperceived web quality. Information \& Management 39 (May): 467-476.

3. Baldwin, A.A., C.E. Brown, and B.S. Trinkle. 2006. XBRL: An impacts framework and research challenge. Journal of Emerging Technologies in Accounting 3 (1): 97-116.

4. Ballou, D.P., and H.L. Pazer. 1995. Designing information systems to optimize the accuracy-timeliness tradeoff. Information Systems Research 6 (1): 51-72.

5. Bay, S., K. Kumaraswamy, M.G. Anderle, R. Kumar, and D.M. Steier. 2006. Large scale detection of irregularities in accounting data. Proceedings of the International Conference on Data Mining (December 18-21): 75-86.

6. Bedard, J.C., C. Jackson, M.L. Ettredge, and K.M. Johnstone. 2003. The effect of training on auditors' acceptance of an electronic work system. International Journal of Accounting Information Systems 4 (December): 227-250.

$7 . \quad$ M.L. Ettredge, C. Jackson, and K.M. Johnstone. 2007. Knowledge, experience and work-around behaviors: Electronic media in the professional audit environment. Working paper, Northeastern University, University of Kansas, and University of Wisconsin. 
8. Boritz, J.E., and W.G. No. 2008. The SEC's XBRL voluntary filing program on EDGAR: A case for quality assurance. Current Issues in Auditing 2(2): A36-A50.

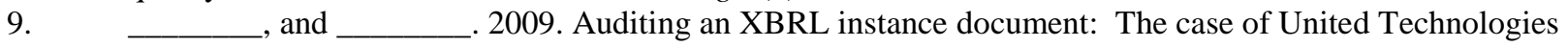
Corporation. Working paper, University of Waterloo.

10. Bonner, S.E. 1999. Judgment and decision-making in accounting. Accounting Horizons 13 (December): 385-398.

11. Bovee, M., A. Kogan, K. Nelson, R.P. Srivastava, and M.A. Vasarhelyi. 2005. Financial reporting and auditing agent with net knowledge (FRANK) and eXtensible Business Reporting Language (XBRL).

Journal of Information Systems 19 (Spring): 19-42.

12. 2007. XBRL and information quality: Promise, progress, and future benefits. Working paper, University of Vermont.

13. Canadian Securities Administrators (CSA). 2007. Canada's securities regulators launch eXtensible Business Reporting Language (XBRL) voluntary filing program. Press release available at: http://www.osc.gov.on.ca/Media/NewsReleases/2007/nr_20070119_csa-xbrl-launch.jsp.

14. Chia, D.K. 2008. Comments on proposed rule on interactive data to improve financial reporting. Available at: http://www.sec.gov/comments/s7-11-08/s71108-69.pdf. August 1.

15. Collopy, F. 1996. Biases in retrospective self-reports of time use: An empirical study of computer users. Management Science 42 (May): 758-767.

16. Comisión Nacional del Mercado de Valores / Spanish Stock Exchange Commission (CNMV). 2005. Spanish stock exchange begins use of XBRL. Press release available at:

http://www.cnmv.es/english/index_e.htm. July 14.

17. Cox, C. 2006. The interactive data revolution: Improved disclosure for investors, less expensive reporting for companies. Speech by the Chairman, SEC, before American Enterprise Institute, Washington D.C., May 30.

18. Davis, F.D. 1989. Perceived usefulness, perceived ease of use, and user acceptance of information technology. MIS Quarterly 13 (September): 319-340.

19. _ R.P. Bagozzi, and P.R. Warshaw. 1989. User acceptance of computer technology: A comparison of two theoretical models. Management Science 35 (August): 982-1003.

20. Debreceny, R., A. Chandra, J. Cheh, D. Guithues-Amrhein, N. Hannon, P. Hutchison, D. Janvrin, R. Jones, B. Lamberton, A. Lymer, M. Mascha, R. Nehmer, S. Roohani, R. Srivastava, S.Trabelsi, T. Tribunella, G. Trites, and M. Vasarhelyi. 2005. Financial reporting in XBRL on the SEC's EDGAR system: A critique and evaluation. Journal of Information Systems 19 (Fall): 191-210.

21. Derby, P. 2005. Better, faster, smarter business reporting using XBRL. Speech by the Managing Executive for Operations and Management, Office of the Chairman, SEC, before the $11^{\text {th }}$ XBRL International Conference, Boston, MA, April 26.

22. DeSanctis, G. 1983. Expectancy theory as an explanation of voluntary use of a decision support system. Psychological Reports (52): 247-260.

23. Doll, W.J., A. Hendrickson, and X. Deng. 1998. Using Davis's perceived usefulness and ease-of-use instruments for decision making: A confirmatory and multigroup invariance analysis. Decision Sciences 29 (4): 839-869.

24. Dragon Tag XBRL Enabler 1.5, Rivet Software, Inc., Englewood, CO.

25. Edberg, D.T., and B.J. Bowman. 1996. User-developed applications: An empirical study of application quality and developer productivity. Journal of Management Information Systems 12 (Summer): 167-185.

26. Farewell, S. 2006. An introduction to XBRL through the use of research and technical assignments. Journal of Information Systems 20 (Spring): 161-186.

27. Federal Deposit Insurance Corporation (FDIC). 2005. Banking agencies announce implementation of webbased central data repository for bank financial data. Press release available at: http://www.fdic.gov/news/news/press/2005/pr0405.html. January 26.

28. Fishbein, M., and I. Ajzen. 1975. Belief, Attitude, Intention and Behavior: An Introduction to Theory and Research. Reading MA: Addison-Wesley.

29. Forster, J., E.T. Higgins, and A.T. Bianco. 2003. Speed/accuracy decisions in task performance: Built-in trade-off or separate strategic concerns? Organizational Behavior and Human Decision Processes 90 (January): 148-164. 
30. Gunn. J. 2007. XBRL: Opportunities and challenges in enhancing financial reporting and assurance processes. Current Issues in Auditing 1: A36-A43.

31. Hannon, N. 2002. XBRL enters a new phase. Strategic Finance 83 (April): 61-2.

32. ___ and G. Trevithick. 2006. Making clean deposits: XBRL is helping the FDIC member banks, and other agencies share data. Strategic Finance 87 (February): 24-29.

33. Heffes, E.M. 2007. FEI CEO's 2007 top 10 financial reporting challenges. Financial Executive (January/February): 14-15.

34. Hodge, F.D., J.J. Kennedy, and L.A. Maines. 2004. Does search-facilitating technology improve the transparency of financial reporting? The Accounting Review 79 (July): 687-703.

35. Hoffman, C., and C. Strand. 2001. XBRL Essentials. New York NY: American Institute of Certified Public Accountants.

36. Hu, P., P. Chan, O. Liu Sheng, and K. Tam. 1999. Examining the technology acceptance model using physician acceptance of telemedicine technology. Journal of Management Information Systems 16 (Fall): 91-112.

37. Interstage XWand Taxonomy Editor/Instance Creator 2.1, Fujitsu Limited, Tokyo, Japan.

38. Janvrin, D., and J. Morrison. 2000. Using a structured design approach to reduce risks in end user spreadsheet development. Information \& Management 37: 1-12.

39. KPMG. 2008. Comments on proposed rule on interactive data to improve financial reporting. Available at: http://www.sec.gov/comments/s7-11-08/s71108-61.pdf. August 1.

40. Lucas, H.C. 1975. Performance and the use of an information system. Management Science 21 (April): 908-919.

41. Ma, Q., and L. Liu. 2004. The technology acceptance model: A meta-analysis of empirical findings. Journal of Organizational and End User Computing 16 (January-March): 59-72.

42. Mahoney, L.S., and C.White, Jr. 2007. Creating XBRL instance documents in Excel. Journal of Accountancy 77 (July): 66-72.

43. Malhotra, Y., and D.F. Galletta. 2004. Building systems that users want to use. Communications of the ACM 47 (December): 89-94.

44. Mamaghani, F. 2002. Evaluation and selection of an antivirus and content filtering software. Information Management \& Computer Security 10 (1): 28-32.

45. Markus, L., and M. Keil. 1994. If we build it, they will come: Designing information systems that people want to use. Sloan Management Review (Summer): 11-25.

46. Mascha, M., D. Janvrin, J. Plouff, and B. Kruger. 2009. XBRL instance document creation: Tools for small-to-medium firms. Strategic Finance, 90(7): 47-53.

47. Mathieson, K. 1991. Predicting user intention: Comparing the technology acceptance model with theory of planned behavior. Information Systems Research 2 (September): 173-191.

48. Maudlin, E.G., and L.V. Ruchala. 1999. Towards a meta-theory of accounting information systems. Accounting, Organizations and Society 24 (May): 317-331.

49. McCloskey, D.W. 2006. The importance of ease of use, usefulness, and trust to online consumers: An examination of the technology acceptance model with older consumers. Journal of Organizational and End User Computing 18 (3): 47-65.

50. Morrison, M., J. Morrison, J. Melrose, and E.V. Wilson. 2002. A visual code inspection approach to reduce spreadsheet linking errors. Journal of End User Computing 14 (July-September): 51-63.

51. Panko, R. R. 2000. Spreadsheet errors: What we know. What we think we can do. Proceedings of the Spreadsheet Risk Symposium, European Spreadsheet Risks Interest Group (EuSpRIG), Greenwich, England, July 17-18.

52. Pedhazur, E., and L.P. Schmelkin. 1991. Measurement, Design, and Analysis: An Integrated Approach. Hillside NJ: Lawrence Erlbaum Associates.

53. Pinsker, R.E. 2007. A theoretical framework for examining the corporate adoption decision involving XBRL as a continuous disclosure business reporting technology. Research Implications of XBRL, edited by M. Piechocki, C. Felden, and R. Debreceny.

54. Phillips, M.E., T.E. Bahmanziari, and R.G. Colvard. 2008. Six steps to XBRL. Journal of Accountancy 205 (February): 34-37.

55. Plumlee, D., and M. Plumlee. 2008. Assurance on XBRL for financial reporting. Accounting Horizons 22 (September): 353-369. 
56. Rappeport, A. 2008. XBRL skeptics abound: Some doubt that interactive financial data will be of much use. CFO.com Available at: http://www.cfo.com/article.cfm/10486715/c 2984268/?f=archives.htm. January 4.

57. Rivet Software. 2007. Dragon Tag XBRL enabler empowers customers such as Microsoft and Ernst \& Young to embrace the XBRL global reporting standard. Press release available at: http://www.edgaronline.com/investor/news/021405.aspx. February 14.

58. Rummel, N. 2008. SEC advisory committee gives thumbs up to XBRL. Financial Week Press release available at: http://www.financialweek.com/apps/pbcs.dll/article?AID=/20080114/REG/646343322/1036. January 14.

59. Securities and Exchange Commission (SEC). 2005. XBRL Voluntary Financial Reporting Program on the EDGAR System. Rule 33-8529. February 3. Washington, D.C.: SEC.

60. 2006a. More companies join SEC's program to use interactive data for financial statements. Press release available at: http://www.sec.gov/news/press/2006/2006-99.htm. June 20.

61. 2006b. SEC to rebuild public disclosure system to make it 'interactive'. Press release available at: http://www.sec.gov/news/press/2006/2006-158.htm. September 25.

62. 2007. SEC Chairman Cox announces landmark progress in providing instant, user-friendly access to financial reporting information for investors. Press release available at: http://www.sec.gov/news/press/2007/2007-200.htm. September 25.

63. 2008a. Advisory committee on improvements to financial reporting. Report available at: http://www.sec.gov/about/offices/oca/acifr/acifr-finalreport.pdf.

64. 2008b. SEC approves interactive data for financial reporting by public companies, mutual funds. Available at: http://www.sec.gov/news/press/2008/2008-300.htm.

65. 2009a. EDGAR Filer Manual (volume II) EDGAR filing (version 11). Available at: http://www.sec.gov/info/edgar/edgarfm-vol2-v11.pdf.

$66 . \quad$ 2009b. Interactive data to improve financial reporting. Available at: http://www.sec.gov/rules/final/2009/33-9002.pdf.

67. Segars, A.H., and V. Grover. 1993. Re-examining perceived ease of use and usefulness: A confirmatory factor analysis. MIS Quarterly 17 (December): 517-527.

68. Srivastava, R.P., and A. Kogan. 2009. Assurance on XBRL instance document: A conceptual framework of assertions. Working paper, University of Kansas and Rutgers University.

69. Stantial, J. 2007. ROI on XBRL. Journal of Accountancy (June): 32-35.

70. Straub, D., M. Limayem, and E. Karahanna-Evariso. 1995. Measuring system usage: Implications for IS theory testing. Management Science 41 (8): 1328-1342.

71. Tie, R. 2005. XBRL: It's unstoppable. Journal of Accountancy (August): 32-35.

72. Trinkle, B.S. and D. Henderson. 2008. XBRL adoption framework. Working Paper, College of Charleston.

73. Twarowski, C. 2008. Financial data 'on steroids': SEC to junk paper filings, require interactive online reports. Washington Post: August 19.

74. Venkatesh, V., and F.D. Davis. 2000. A theoretical extension of the technology acceptance model: four longitudinal field studies. Management Science 46 (2): 186-204.

75. _ M.G. Morris, G.B. Davis, and F.D. Davis. 2003. User acceptance of information technology: Toward a unified view. MIS Quarterly 27 (July): 425-478.

76. Walsh, S.T., and C.G. White. 2000. Congress's goal of increasing electronic filing: An assessment based on the technology-adoption literature. Accounting Horizons 14 (December): 403-425.

77. West, T.D., and F.D. Davis. 2008. Antecedents and consequences of adopting performance-based budgets. Working paper, Northern Illinois University and University of Arkansas.

78. White, Clinton E Jr. 2008. The Accountant's Guide to XBRL. Chapter 1. http://www.skipwhite.com.

79. Willis, M. 2005. XBRL and data standardization: Transforming the way cpas work. Journal of Accountancy (March): 80-81.

80. XBRL US, Inc. 2008. XBRL US GAAP Taxonomy Preparers Guide. Available at: http://www.xbrl.us/preparersguide/Pages/default.aspx. 


\section{APPENDIX A}

Framework Demonstration Financial Information Used to Extend Taxonomy and Create Instance Document

Panel A: Income Statement

\begin{tabular}{|c|c|c|c|}
\hline & fx Earnings before Interest \& Taxes & & \\
\hline & $\mathrm{A}$ & B & C \\
\hline 1 & \multicolumn{2}{|l|}{ Lily's Flowers } & \\
\hline 2 & \multicolumn{2}{|l|}{ Income Statement } & \\
\hline 3 & \multicolumn{2}{|l|}{ Period Ending 12/31/2007 } & \\
\hline 4 & & & \\
\hline 5 & Net Sales & $\$ 2,500$ & \\
\hline 6 & Cost of Goods Sold & 1750 & \\
\hline 7 & Gross Profit & 750 & \\
\hline 8 & Selling Expenses & 500 & \\
\hline 9 & Earnings before Interest \& Taxes & 250 & \\
\hline 10 & Interest \& Taxes & 135 & \\
\hline 11 & Net Income & $\$ 115$ & \\
\hline 12 & & & \\
\hline 13 & & & \\
\hline 14 & & & \\
\hline
\end{tabular}

Panel B: Statement of Financial Position

\begin{tabular}{|c|c|c|c|}
\hline \multirow[t]{2}{*}{$\mathrm{C}$} & \multicolumn{3}{|l|}{$f x$} \\
\hline & A & B & $\mathrm{C}$ \\
\hline 1 & \multicolumn{2}{|l|}{ Lily's Flowers } & \\
\hline 2 & \multicolumn{2}{|c|}{ Statement of Financial Position } & \\
\hline 3 & \multicolumn{2}{|l|}{ December 31, 2007} & \\
\hline 4 & & & \\
\hline 5 & Cash \& Cash Equivalents & $\$ 75$ & \\
\hline 6 & Accounts Receivable & 235 & \\
\hline 7 & Flowers Inventory & 155 & \\
\hline 8 & Other Inventory & 95 & \\
\hline 9 & Property, Plant and Equipment & 215 & \\
\hline 10 & Total Assets & $\$ 775$ & \\
\hline 11 & Accounts Payable & $\$ 225$ & \\
\hline 12 & Notes Payable & 175 & \\
\hline 13 & Common Stock & 198 & \\
\hline 14 & Retained Earnings & 177 & \\
\hline 15 & Total Liabitlies and Equity & $\$ 775$ & \\
\hline 16 & & & \\
\hline 17 & & & \\
\hline
\end{tabular}




\section{APPENDIX B}

\section{Framework Demonstration Pre-Project Questionnaire}

1. How many times have you created an instance document?

zero
once
twice
more than twice

2. How many times have you worked with Dragon Tag software?

zero
once
twice


more than twice

2a. If you have worked with Dragon Tag, in what context?

3. How many times have you worked with Interstage XWand software?

zero
once
twice
more than twice

3a. If you have worked with Interstage XWand, in what context?

4. Rate your knowledge of XBRL

$\begin{array}{ccccccc}1 & 2 & 4 & 5 & 6 & 7 \\ \text { Novice } & 2 & & & & \text { Expert }\end{array}$

5. Rate your knowledge of financial reporting

$\begin{array}{llllllc}1 & 2 & 3 & 4 & 5 & 6 & 7 \\ \text { Novice } & & & & & \text { Expert }\end{array}$

6. Rate your knowledge of taxonomies

$\begin{array}{llllllc}1 & 2 & 3 & 5 & 6 & 7 \\ \text { Novice } & & & & & \text { Expert }\end{array}$

7. Rate your knowledge of how to extend a taxonomy

$\begin{array}{lcccccc}1 & 2 & 3 & 4 & 5 & 6 & 7 \\ \text { Novice } & & & & & \text { Expert }\end{array}$

8. What semester did you take introduction to financial accounting?

9. When did you take intermediate accounting I? 


\section{Specific knowledge questions:}

10. An instance document is:
a. a document that lists income statement accounts
b. a document that matches the chart of accounts to the financial statements
c. a document that matches each account with an element from a taxonomy
d. I don't know

11. A taxonomy is:
a. a method to sort the chart of accounts
b. a listing of elements actually used
c. a listing of elements with a unique identifier
d. I don't know

12. XBRL:
a. converts financial statements into spreadsheets
b. converts financial data into electronic data readable by any computer
c. converts all data, financial and non-financial, into electronic data readable by any computer
d. I don't know

13. Taxonomies can be:
a. extended by each organization
b. cannot be changed
c. are dictated by the SEC
d. I don't know

14. Rate your comfort level with learning new software
1
2
3
4
Novice
5
6
7
Expert

15. Rate your comfort level with computers in general
1
2
3
4
5
6
Expert

16. How many college-level IS/IT/computer courses have you had (include all courses in which you are currently registered)?

\section{Do you agree/disagree with the following statements?}

17. "I do not find it easy to learn new software."
1
2
3
4
5
6
7
Disagree
(1)
Agree

18. "I enjoy trying new software."

$\begin{array}{lrlllll}1 & 2 & 3 & 4 & 5 & 6 & 7 \\ \text { Disagree } & & & & & & \text { Agree }\end{array}$

19. "I think computers are boring."
1
2
3
4
5
6
7
Agree 


\section{APPENDIX C}

\section{Framework Demonstration Post-Project Questionnaire}

1. Rate your knowledge of XBRL
1
2
3
4
Expert
Novice

4 Expert

2. Rate your knowledge of financial reporting
1
2
3
4
Expert

3. Rate your knowledge of taxonomies
$1 \quad 2 \quad 3$
Novice

3

4

Expert $^{5}$

4. Rate your knowledge of how to extend a taxonomy
1
2
3
4
5
Novice

\section{Specific knowledge questions:}

5. An instance document is:
a. a document that lists income statement accounts
b. a document that matches the chart of accounts to the financial statements
c. a document that matches each account with an element from a taxonomy
d. I don't know

6. A taxonomy is:
a. a method to sort the chart of accounts
b. a listing of elements actually used
c. a listing of elements with a unique identifier
d. I don't know

7. XBRL:
a. converts financial statements into spreadsheets
b. $\quad$ converts financial data into electronic data readable by any computer
c. converts all data, financial and non-financial, into electronic data readable by any computer
d. I don't know

8. Taxonomies can be:
a. extended by each organization
b. cannot be changed
c. are dictated by the SEC
d. I don't know

9. Rate your comfort level with learning new software
1
2
Novice
4
Expert

10. Rate your comfort level with computers in general
1
2
3
4
Novice
5
Expert


For the following three questions, indicate if you agree or disagree with the statements.

11. "I do not find it easy to learn new software."

$\begin{array}{lcccc}1 & 2 & 3 & 4 & 5 \\ \text { Strongly } & & & \text { Strongly } \\ \text { Disagree } & & & \text { Agree }\end{array}$

12. "I enjoy trying new software."

$\begin{array}{lcccc}1 & 3 & 4 & 5 \\ \text { Strongly } & 2 & 3 & \text { Strongly } \\ \text { Disagree } & & & \text { Agree }\end{array}$

13. "I think computers are boring."

$\begin{array}{lllll}1 & 2 & 3 & 4 & 5 \\ \text { Strongly } & & & \begin{array}{c}\text { Strongly } \\ \text { Agree }\end{array} \\ \text { Disagree } & & & \end{array}$

14. Using Dragon Tag improved the quality of the XBRL instance document preparation process.

$\begin{array}{llccc}1 & 2 & 3 & 4 & 5 \\ \text { Strongly } & & & & \text { Strongly } \\ \text { Disagree } & & & \text { Agree }\end{array}$

15. Dragon Tag supports critical aspects of the XBRL instance document preparation process.
Strongly
2
3
4
Disagree
Strongly
Agree

16. Dragon Tag enabled me to accomplish the XBRL instance document preparation task quickly.
Strongly
Disagree
2
3
4
Strongly
Agree

${ }^{a}$ Questionnaire for participants using Dragon Tag.Software. Software name was changed to Interstage XWand for participants in Interstage XWand treatment condition.

17. Using Dragon Tag allowed me to accomplish more work than would otherwise be possible.
Strongly
2
3
4
5
Disagree
Strongly
Agree

18. Using Dragon Tag increased the effectiveness of the XBRL instance document preparation process.
Strongly
Disagree
2
3
4
Strongly
Agree

19. Dragon Tag made it easier for me to prepare XBRL instance documents.
1
Strongly
Disagree
2
3
4
Strongly
Agree

20. Dragon Tag made it easier for me to extend an existing XBRL taxonomy.
1
2
Strongly
Disagree
3
4
Strongly
Agree 
21. Overall, I find the Dragon Tag system useful for XBRL instance document preparation.

$\begin{array}{lllcc}1 & 2 & 3 & 4 & 5 \\ \text { Strongly } & & & & \begin{array}{c}\text { Strongly } \\ \text { Agree }\end{array} \\ \text { Disagree } & & & \end{array}$

22. Learning to use the Dragon Tag system was easy for me.

$\begin{array}{lllcc}1 & 2 & 3 & 4 & 5 \\ \text { Strongly } & & & \text { Strongly } \\ \text { Disagree } & & & \text { Agree }\end{array}$

23. I found it easy to get Dragon Tag to do what I want to do.

$\begin{array}{lllll}1 & 2 & 3 & 4 & 5 \\ \text { Strongly } & & & & \text { Strongly } \\ \text { Disagree } & & & \text { Agree }\end{array}$

24. Dragon Tag is rigid and inflexible to interact with.
Strongly
Disagree
23
4
Strongly
Agree

25. My interaction with Dragon Tag was clear and understandable.
Strongly
2
3
$4 \quad 5$
Disagree
Strongly
Agree

26. I find it takes a lot of effort to become skillful at using Dragon Tag.

$\begin{array}{lllcc}1 & 2 & 3 & 4 & 5 \\ \text { Strongly } & & & & \text { Strongly } \\ \text { Disagree } & & & \text { Agree }\end{array}$

27. Overall, I found Dragon Tag easy to use.

$\begin{array}{lllcc}1 & 2 & 3 & 4 & 5 \\ \text { Strongly } & & & & \text { Strongly } \\ \text { Disagree } & & & \text { Agree }\end{array}$

28. I felt I always knew what stage of the XBRL instance document preparation process I was in.

$\begin{array}{lllcc}1 & 2 & 3 & 4 & 5 \\ \text { Strongly } & & & & \text { Strongly } \\ \text { Disagree } & & & \text { Agree }\end{array}$

29. The Dragon Tag system indicated to me when an error occurred.
Strongly
2
3
$4 \quad 5$
Strongly
Disagree
Agree

30. The Dragon Tag system made it easy for me to select between alternative taxonomies.
1
Strongly
Disagree
45
Strongly
Agree

31. Dragon Tag made it harder for me to extend an existing XBRL taxonomy.
1
2
3
Strongly
Disagree
Strongly
Agree 
32. I found the directions for learning Dragon Tag easy to understand.

$\begin{array}{lllll}1 & 2 & 3 & 4 & 5 \\ \text { Strongly } & & & & \begin{array}{c}\text { Strongly } \\ \text { Agree }\end{array}\end{array}$

33. Estimate how long you spent completing this assignment using Dragon Tag

\begin{tabular}{|c|c|}
\hline \multicolumn{2}{|l|}{$\ldots$} \\
\hline & to 29 minutes \\
\hline & to 44 minutes \\
\hline & $\begin{array}{l}45 \text { to } 59 \text { minutes } \\
60 \text { to } 74 \text { minutes }\end{array}$ \\
\hline & over 75 minutes \\
\hline
\end{tabular}

34. List three advantages of using Dragon Tag to create instance documents:
a)
b)
c)

35. List three challenges you experienced while using Dragon Tag to create instance documents:
a)
b)
c)

36. List three advantages of using Dragon Tag to extend a taxonomy:
a)
b)
c)

37. List three challenges you experienced while using Dragon Tag to extend a taxonomy:

a)

b)

c) 


\section{APPENDIX D}

\section{Framework Demonstration Technology Acceptance Mean Ratings and Associated Levels of Reliability ${ }^{\mathrm{a}}$} $\mathrm{n}=\mathbf{2 1 6}$

\section{Panel A: Perceived Usefulness}

\begin{tabular}{cc}
$\begin{array}{c}\text { Interstage } \\
\text { Dragon }\end{array}$ & $\begin{array}{c}\text { XWand } \\
\text { Tag Means } \\
\text { Means (Std }\end{array}$ \\
\hline (Std Dev) & Dev) \\
[alphas] & [alphas
\end{tabular}

Software to create instance documents enabled me to accomplish the XBRL instance document preparation task more quickly

Using software to create instance documents allowed me to accomplish more

Using software to create instance documents increased the effectiveness of the XBRL instance document preparation process

Software to create instance documents made it easier for me to prepare

Overall, I find the software useful for the XBRL instance document

Overall perceived usefulness

${ }^{a}$ Based on five point Likert scale where $1=$ strongly disagree and $5=$ strongly agree. Means, standard deviations, and associated levels of reliability (i.e., Cronbach's alpha) are reported.

${ }^{\mathrm{b}}$ Question was reverse coded.

$* *$ Two tailed $\mathrm{t}$ test analysis indicates responses differ by software at $\mathrm{p} \leq 0.01$ level.

* Two tailed $t$ test analysis indicates responses differ by software at $\mathrm{p} \leq 0.05$ level. 


\begin{tabular}{|c|c|}
\hline & Interstage \\
\hline $\begin{array}{r}\text { Drago } \\
\text { Tag Me }\end{array}$ & $\begin{array}{c}\text { Xwand } \\
\text { Means (Std }\end{array}$ \\
\hline$\frac{\text { (Std Dev) }}{\text { [alphas }]}$ & $\frac{\text { Dev) }}{\text { [alphas] }}$ \\
\hline
\end{tabular}

\section{Panel B: Perceived Ease of Use}

Learning to use the software to create instance documents was easy for me

I found it easy to get the software to create instance documents to do what I

The software to create instance documents is rigid and inflexible to interact with ${ }^{\mathrm{b}}$

My interaction with the software to create instance documents was clear and

I find it takes a lot of effort to become skillful at using software to create

Overall, I found the software to create instance documents easy to use

$\begin{array}{rl}3.29 & 2.94 * * \\ (0.98) & (0.91) \\ {[0.79]} & {[0.83]} \\ & \\ 3.01 & 2.70 * * \\ (0.66) & (0.67)\end{array}$

Overall perceived ease of use

\footnotetext{
${ }^{a}$ Based on five point Likert scale where $1=$ strongly disagree and $5=$ strongly agree. Means, standard deviations, and associated levels of reliability (i.e., Cronbach's alpha) are reported.

${ }^{\mathrm{b}}$ Question was reverse coded.

** Two tailed t test analysis indicates responses differ by software at $\mathrm{p} \leq 0.01$ level.

* Two tailed $\mathrm{t}$ test analysis indicates responses differ by software at $\mathrm{p} \leq 0.05$ level.
} 